\title{
ANALISIS KEMAMPUAN MAHASISWA PGMI STAI DARUL ULUM KANDANGAN DALAM MERANCANG RPP TEMATIK
}

\author{
Fitriah \\ STAI Darul Ulum Kandangan, Kalimantan Selatan, Indonesia \\ Email: elbanjaryfitri@gmail.com
}

\author{
Website: \\ https://jurnal.uinantasari.ac.id/index.php/adzka \\ Received: 22 Juni 2020; Accepted: 7 Desember 2020; Published: 21 Desember 2020 \\ DOI: $\underline{10.18952 / \text { aladzkapgmi.v10i2.3734 }}$
}

\begin{abstract}
The research aimed to know the students' ability at Teacher Education of Madrasah Ibtidaiyah Islamic College of Darul Ulum Kandangan in designing thematic lesson plan and to describe the students' problem in designing thematic lesson plan. This research is descriptive quantitative research. The population is all the students of Teacher Education of Madrasah Ibtidaiyah. The sample of the research is 31 students, who took the Planning and Learning strategy subject. The data in this research was taken by documentation and some questions were answered by students as the interviewee. Then the data were analyzed by using the descriptive statistical technique. This research found that the students' ability was categorized well enough with the mean score 60.9. The result of the research also showed that the students were difficult to determine and to formulate the competence objective indicator, learning objective, method, media, learning source, learning activity, and assessment.
\end{abstract}

Key Words: student's ability; thematic lesson plan; planning

\begin{abstract}
ABSTRAK
Penelitian ini bertujuan untuk mengetahui kemampuan mahasiswa Pendidikan Guru Madrasah Ibtidaiyah STAI Darul Ulum Kandangan dalam merancang RPP Tematik, dan mendeskripsikan kendala yang dihadapi oleh mahasiswa Pendidikan Guru Madrasah Ibtidaiyah STAI Darul Ulum Kandangan dalam merancang RPP Tematik. Penelitian ini merupakan penelitian kuantitatif deskriptif Populasi penelitian ini adalah seluruh mahasiswa Pendidikan Guru Madrasah Ibtidaiyah STAI Darul Ulum Kandangan. Adapun sampel dalam penelitian adalah mahasiswa Pendidikan Guru Madrasah Ibtidaiyah semester IV yang mengikuti mata kuliah Perencanaan dan Strategi Pembelajaran sebanyak 31 orang. Teknik pengumpulan data melului dokumentasi dan wawancara. Kemudian data dianalisis menggunakan teknis statistik deskriptif. Hasil penelitian menunjukkan bahwa kemampuan mahasiswa Pendidikan Guru Madrasah Ibtidaiyah STAI Darul Ulum Kandangan dalam merancang RPP Tematik pada mata kuliah Strategi dan Perencanaan Pembelajaran dikategorikan "Cukup Baik" dengan rata-rata kelas sebesar 60,9 dan kendala yang dihadapi mahasiswa selama merancang RPP Tematik diantaranya ialah perumusan indikator pencapaian kompetensi (IPK), perumusan tujuan pembelajaran, memilih metode, media dan sumber belajar, kegiatan pembelajaran, dan penilaian.
\end{abstract}

Kata Kunci: kemampuan mahasiswa; RPP Tematik; merancang 


\section{PENDAHULUAN}

Pendidikan di Indonesia telah diatur sedemikian rupa melalui kurikulum, mulai dari proses perencanaan sampai pada evaluasi. Berdasarkan UU Nomor 20 Tahun 2003 tentang Sistem Pendidikan Nasioanal, kurikulum merupakan sebuah rencana dan aturan mengenai tujuan, isi dan bahan pelajaran, serta metode dalam melaksanakan kegiatan pembelajaran agar mencapai tujuan pendidikan yng telah ditentukan (Depdiknas, 2003) Kurikulum juga diartikan sebagai rencana dan aturan mengenai tujuan, isi, dan bahan pelajaran, serta cara yang digunakan dalam penyelenggaraan kegiatan pembelajaran untuk mengoptimalkan perkembangan peserta didik dan mampu mencapai tujuan pendidikan tertentu (Widyastono, 2015).

Kurikulum dalam dunia pendidikan memiliki kedudukan yang sangat penting sebagai pedoman dasar dalam melaksanakan kegiatan pendidikan. Kurikulum juga merupakan salah satu faktor yang mempengaruhi mutu kegiatan belajar-mengajar di sekolah, disamping faktor lainnya seperi guru, sarana prasarana, manajemen dan input siswa itu sendiri. Jika kegiatan belajar mengajar bermutu maka akan meningkatkan mutu lulusan. Maknanya, kurikulum merupakan ciri yang paling utama dalam sebuah pendidikan di sekolah. Selain itu dengan adanya kurikulum dapat mengarahkan berbagai aktivitas pendidikan demi tercapainya tujuan pendidikan yang telah dirumuskan (Widyastono, 2015). Dengan demikian dapat dipahami bahwa kurikulum merupakan acuan dasar dalam melaksanakan pendidikan.

Adapun kurikulum yang digunakan saat ini adalah kurikulum 2013 sebagai pengembangan dari kurikulum sebelumnya yakni KTSP. Pengembangan kurikulum saat ini dititikberatkan pada empat aspek, yakni Standar Kompetensi Lulusan (SKL), Standar Isi (SI), Standar Proses, dan Standar Penilaian. Oleh karena itu, dengan berlakunya kurikulum baru tersebut, tentunya memerlukan persiapan, pemahaman dan keterampilan dalam melaksanakan kurikulum, bagi seluruh pengambil kebijakan dan para pelaksana di lapangan. Hal ini tidak lain agar tujuan dari pengembangan kurikulum ini dapat terealisasikan dengan maksimal dan tujuan pendidikan nasional dapat tercapai.

Sebagai bentuk dari pengembangan kurikulum, Pembelajaran yang digunakan diarahkan pada pembelajaran tematik. Pembelajaran tematik merupakan istilah pembelajaran yang sangat familiar di telinga kita akhir-akhir ini, terutama bagi para praktisi pendidikan. Pembelajaran tematik ialah pembelajaran yang dilaksankan berdasarkan Kurikulum 2013 adalah salah satu strategi pembelajaran terpadu yang menggunakan tema untuk mengaitkan beberapa mata pelajaran, Sehingga dengan pembelajaran tersebut dapat memberikan pengalaman yang bermakna bagi siswa (Hartono, 2013). Pembelajaran pada tingkat sekolah dasar dirancang dengan menggunakan jaringan tema tertentu untuk mencapai kompetensi tertentu. Sehingga dengan pembelajaran tematik ini, batasan antar mata pelajaran tidak terlalu jelas dan tentunya siswa merasa lebih tertarik.

Pembelajaran tematik dipahami sebagai kegiatan pembelajaran yang dilaksanakan sesuai dengan tema-tema tertentu (Suseno T. I.-T., 2017). Pembelajaran tematik juga diartikan sebagai sebuah pembelajaran yang menggunakan tema untuk mengaitkan beberapa pelajaran agar dapat memberikan pengalaman bermakna kepada siswa. pembelajaran tematik juga diartikan sebagai suatu pendekatan pembelajaran yang memadukan beberapa kompetensi dasar (KD) dan indikator dari kurikulum atau Standar isi (SI) dari beberapa mata pelajaran sehingga menjadi satu kesatuan dan akhirnya menjadi sebuah tema. (Daryanto, 2014)

Pembelajaran tematik merupakan didefinisikan sebagai model pembelajaran terpadu yang menggunakan pendekatan tematik. Di mana melibatkan beberapa mata pelajaran agar siswa dapat memahami konsep-konsep yang mereka pelajari melalui pengalaman langsung dan dihubungkan dengan konsep lain yang telah dipelajarinya. Selain itu, pembelajaran tematik mampu membuat aktivitas pembelajaran menjadi relevan dan penuh makna bagi siswa. Pada pembelajaran tematik, kegiatannya memadukan antara pengetahuan, keterampilan 
dan sikap, serta nilai dan kreativitas pembelajaran melalui tema. Pembelajaran yang demikian juga disebut dengan pembelajaran terpadu, yakni melibatkan beberapa materi pembelajaran yang diikat menjadi tema-tema tertentu. Pembelajaran tematik ini pada pelaksanaannya di lapangan dititikberatkan pada guru kelas, tidak lagi pada guru mata pelajaran. Sehingga perlunya pemahaman guru kelas terhadap sistem pembelajaran tematik ini agar pembelajaran yang dilaksanakan efektif dan bermakna (Prastowo, 2019).

Menurut Trianto yang dikutip oleh Prastowo menyebutkan bahwa, pembelajaran tematik merupakan salah satu model pembelajaran yang terpadu pada jenjang taman KanakKanak (TKIRA) atau Sekolah Dasar untuk kelas awal (kelas 1,2 dan 3) yang didasarkan pada tema-tema tertentu,di manatema-tema tersebut merupakan tema yang kontekstual bagi dunia anak. Maka dari itu, kurikulum yang berlaku saat ini sangat mengedepankan untuk menggunakan yang menggunakan tema-tema tertentu dengan menggabungkan beberapa mata pelajaran pada jenjang MISSD (Prastowo, 2019).

1. Karakteristik Pembelajaran Tematik

Sebagai sebuah model pembelajaran yang diterapkan di sekolah dasar, berikut karakteristik pembelajaran tematik (Daryanto, 2013).

a. Berpusat pada siswa, model ini memosisikan siswa sebagai subjek belajar, bukan objek. Guru berperan sebagai fasilitator untuk kemudahan belajar.

b. Memberikan pengalaman langsung

c. Pemisahan antar mata pelajaran tidak terlalu jelas

d. Menyajikan konsep dari berbagai mata pelajaran

e. Bersifat fleksibel

f. Hasil pembelajaran sesuai dengan minat dan kebutuhan siswa

g. Menggunakan prinsip belajar sambil bermain dan menyenangkan.

Berdasarkan penjelasan tersebut dapat dipahami bahwa, pembelajaran tematik merupakan pembelajaran yang memiliki ciri-ciri sebagai kegiatan pembelajaran yang menempatkan siswa sebagai subjek belajar, bukan lagi objek, memberikan pembelajaran melalui pengalaman langsung dengan berbagai aktivitas pembelajaran dan menggunakan tema-tema tertentu dalam setiap proses pembelajaran, serta dapat memberikan siswa kesempatan belajar sesuai dengan minat dan kebutuhan siswa.

2. Tujuan Pembelajaran Tematik

Sebelum membahas tujuan dari pembelajaran tematik ini, alangkah baiknya diuraikan terlebih dahulu alas an atau dasar yang menjadikan model pembelajaran ini dianjurkan untuk diimplementasikan pada pembelajaran di jenjang SD IMI. Sebagaimana yang diungkapkan oleh Mamat SB, dan kawan-kawan, yang dikutip oleh Prastowo dijelaskan bahwa ada beberapa alasan yang menjadi dasar perlunya menggunakan model ini dalam kegiatan pembelajaran SDIMI sebagai berikut:

a. Pendekatan tematik mengharuskan perubahan paradigm dalam mengajar, yakni siswa bukan lagi sebagai objek melainkan subjek, sehingga pembelajaran harus berpusat kepada siswa (student centered).

b. Pembelajaran ini merupakan pendekatan pembelajaran yang disesuaikan dengan perkembangan siswa dan sesuai dengan kecenderungananak usia antara 0 sampai 8 tahun.

c. Memungkinkan untuk menggabungkan berbagai perspektif dan kajian interdisipliner dalam memahami suatu tema tertentu.

d. Mendorong siswa untuk lebih memahami wacana secara aktual dan kontekstual.

e. Menuntut penerapan metodologipembelajaran yang bervariasi (Prastowo, 2019).

Berdasarkan buku Pedoman Penyusunan Pembelajaran tematik Pendidikan Agama Islam (PAI) Sekolah Dasar (SD) telah disebutkan bahwa tujuan dari pembelajaran tematik adalah agar siswa memusatkan perhatian pada tema tertentu, agar siswa mampu belajar dan mengembangkan pengetahuan dan kompetensi dasar dalam tema, agar pemahaman siswa 
terhadap materi lebih dalam, agar kompetensi dasar siswa dapat dikembangkan lebih baik, dan agar guru dapat menggunakan waktu lebih hemat karena pembelajarannya disajikan secara sistematis (Depag RI, 2009). Pada dasarnya pembelajaran tematik ini digunakan dengan tujuan untuk mempermudah siswa memahami pembelajaran dan membantu guru dalam menghemat waktu pembelajaran. Sehingga waktu yang tersisa dapat digunaan untuk memantapkan materi dan membina keterampilan sikap siswa.

Ada satu hal yang menarik untuk disoroti sebagai akibat dari pengembangan kurikulum. Selain dituntut untuk menguasai pembelajaran tematik, yang tidak kalah penting adalah seorang guru harus mampu merencanakan pembelajaran dengan baik. RPP harus didesain sesuai dengan materi pembelajaran yang menggunakan tema tertentu, tidak lagi per mata pelajaran seperti kurikulum sebelumnya. Hal ini merupakan tantangan tersendiri bagi guru sekolah dasar saat ini.

Pada kehidupan sehari-hari kita sering membuat sebuah rencana sebelum beraktivitas. Hal tersebut tidak lain agar apa yang kita lakukan dapat terlaksana dengan baik dan mencapai tujuan yang dimaksud. Sama halnya dalam dunia pendidikan, seorang guru hendaknya memiliki rencana ketika melaksanakan proses pembelajaran. Hal ini dilakukan guru sebagai upaya agar peserta didiknya dapat belajar dengan maksinal, sehingga pada akhirnya tujuan pembelajaran dapat tercapai, baik dari segi pengetahuan, keterampilan, maupun kepribadian. (Sundayana, 2017). Sebagai salah satu profesi, guru merupakan jabatan yang menuntut keprofesionalan, sudah seharusnya guru mendesain rencana pembelajaran, agar proses pembelajaran dapat berjalan sesuai dengan tujuan dan sasaran yang ingin dicapai (Suhendra, 2019). Berdasarkan uraian tersebut dipahami bahwa, RPP merupakan suatu rencana terkait pembelajaran yang dibuat oleh guru. Pada Permendikbud Nomor 19 Tahun 2014 tentang Pembelajaran pada Pendidikan Dasar dan Menengah, menyebutkan bahwa RPP yang dikembangkan harus mengacu pada silabus, buku teks pelajaran, dan buku panduan guru (Kemdikbud, 2014).

RPP dapat juga diartikan sebagai suatu cara yang memuaskan untuk membuat pembelajaran agar berjalan dengan baik, di mana perencanaan tersebut disertai dengan langkah-lamgkah antisipatif dan dapat membentuk watak, peradaban serta mampu meningkatkan mutu kehidupan siswa (Prastowo, 2019). Oleh karena itu, guru berkewajiban merancang RPP secara lengkap dan sistematis. Komponen-komponen RPP telah diatur dalan Permendikbud Nomor 103 tahun 2014 tentang Pembelajaran pada Pendidikan Dasar dan Menengah. Adapun komponen-komponen dalam RPP diantaranya mencakup identitas (nama sekolahlmadrasah, mata pelajaran, dan kelaslsemester), alokasi waktu, KI-KD, Indikator Pencapaian Kompetensi (IPK), materi pembelajaran, kegiatan pembelajaran, penilaian dan medialalat, bahan dan sumber belajar (Kemdikbud, 2014) Lebih lanjut berdasarkan Permendikbud RI Nomor 22 Tahun 2016 tentang Standar Proses Pendidikan Dasar dan Menengah, dijelaskan pada bagian lampiran bahwa, RPP merupakan rencana kegiatan pembelajaran tatap muka yang dirancang untuk satu kali pertemuan atau lebih (Kemdikbud, 2016). RPP dikembangkan dari silabus untuk mengarahkan kegiatan pembelajaran peserta didik dalam upaya mencapai Kompetensi Dasar (KD). Maka setiap guru pada satuan pendidikan tertentu berkewajiban menyusun RPP yang lengkap dan sistematis, hal ini bertujuan agar pembelajaran berlangsung secara efektif dan dapat memotivasi siswa. RPP hendaknya disusun berdasarkan KD atau subtema yang dilaksanakan sekali pertemuan atau lebih (Kemdikbud, 2016).

Berdasarkan uraian di atas, dapat dipahami bahwa RPP dibuat guru dan garus memuat beberapa komponen dalam pembuatannya. Selain RPP itu, bisa juga diartikan sebagai rencana pengembangan prosedur dan pengorganisasian pembelajaran. Oleh karena itu, bagi setiap guru pada satuan pendidikan tertentu memiliki kewajiban untuk merancang RPP dengan lengkap dan sistematis, serta komponennya harus disesuaikan dengan ketentuan yang 
berlaku.merancang RPP bukan suatu hal yang sia-sia. Berikut diuraikan tujuan dari merancang RPP sebagai berikut;

1. Mengembangkan kreativitas dan inovasi guru dalam membuat RPP merupakansalah satu dari tujuan merancang RPP bgi guru. RPP merupakan instrument pembelajaran yang dapat memudahkan dan meningkatkan kualitas proses pembelajaran.

2. Merancang RPP disesuaikan dengan kondisi lingkungan sekolah, karena setiap satuan pendidikan memiliki keragaman sumber daya. Maka semestinya RPP harus memunculkan keragaman tersebut.

3. Merancang RPP dapat mengembangkan dan meningkatkan profesionalisme guru, hal ini jelas sangat penting bagi perkembangan karier guru. Tentutidak dapat diaktakan professional kalau merancang RPP saja belum mampu (Suseno T. I.-T., 2017)

Dari uraian tersebut dapat dipahami bahwa RPP merupakan sebuah rancangan pembelajaran yang harus dirancang oleh guru sebagai upaya agar pembelajaran dapat berjalan dengan efisien. Jika pembelajaran berjalan dengan efesien, maka pembelajaran dapat mencapai tujuan yang telah ditentukan.

Memperhatikan fenomena yang telah disebutkan sebelumnya, tentu hal tersebut tidak hanya penting untuk para guru setingkat sekolah dasar, akan tetapi juga penting bagi para mahasiswa calon guru untuk mendapatkan pengetahuan dan keterampilan terkait desain RPP Tematik yang sesuai dengan kurikulum 2013. Mengingat mahasiswa calon guru khususnya yang mengambil jurusan guru setingkat sekolah dasar, dalam hal ini adalah mahasiswa Program Studi Pendidikan Guru Madrasah Ibtidaiyah, yang mana mereka telah dibekali pengetahuan terkait perencanaan pembelajaran melalui mata kuliah Perencanaan dan Strategi Pembelajaran sebagai salah satu mata kuliah wajib. Maka mutlak bagi mereka untuk terus mengikuti perkembangan kurikulum dan suatu keharusan untuk dapat mendesain RPP dengan baik. Oleh karena itu, perlu kiranya untuk memetakan kemampuan mahasiswa Program Studi Pendidikan Guru Madrasah Ibtidaiyah dalam membuat RPP Tematik.

Maka, tujuan dari penelitian ini adalah mengetahui kemampuan mahasiswa Pendidikan Guru Madrasah Ibtidaiyah STAI Darul Ulum Kandangan dalam merancang RPP Tematik dan mendeskripsikan kendala yang dihadapi oleh mahasiswa Pendidikan Guru Madrasah Ibtidaiyah STAI Darul Ulum Kandangan dalam merencang RPP Tematik.

\section{METODE PENELITIAN}

Jenis penelitian yang digunakan adalah penelitian deskriptif dengan menggunakan pendekatan kuantitatif yang akan menjelaskan fakta-fakta terkait kemampuan mahasiswa Pendidikan Guru Madrasah Ibtidaiyah STAI Darul Ulum Kandangan dalam merancang RPP Tematik. Populasi penelitian ini adalah seluruh mahasiswa Pendidikan Guru Madrasah Ibtidaiyah STAI Darul Ulum Kandangan. Sampel dalam penelitian adalah mahasiswa Pendidikan Guru Madrasah Ibtidaiyah semester IV yang mengikuti mata kuliah Perencanaan dan Strategi Pembelajaran sebanyak 31 orang yang terdiri dari 4 orang mahasiswa laki-laki dan 27 orang mahasiswa perempuan.

Teknik pengumpulan data yang digunakan melalui: (1) Dokumentasi ialah cara mengumpulkan data terkait permasalahan atau data dalam penelitian, sehingga menghasilkan catatan-catatan penting yang sahih (Suwandi, 2008). Maksudnya ialah mengumpulkan RPP hasil rancangan mahasiswa dan peraturan terkait RPP dan (2) Wawancara dilakukan untuk menggali data terkait kendala-kendala yang dihadapi mahasiswa selama merancang RPP. Jenis wawancara yang digunakan adalah semi terstruktur, dimana ada beberapa pertanyaan yang telah disediakan. Untuk menggali lebih dalam informasi maka akan diberikan pertanyaan lebih lanjut.

Instrumen yang digunakan dalam penelitian ini terdiri dari pedoman wawancara terkait rancangan RPP dan kendala-kendala yang dihadapi dan rubrik penilaian RPP 
berdasarkan Instrumen Penilaian Kinerja Guru (IPKG-1) dalam Menyusun Rencana Pembelajaran berdasarkan Instrumen Penilaian Kinerja Guru oleh Departemen Pendidikan Nasional tahun 2008 dan Lampiran Instrumen Penilaian Kinerja Guru dan menurut Permendikbud Tahun 2016 Standar Proses Pendidikan Dasar dan Menengah yang telah dimodifikasi sesuai kebutuhan peneliti. Adapun rumus untuk menganalisis RPP tematik mahasiswa dengan rumus sebagai berikut.

$$
\mathrm{R}=\frac{\sum 1+(\mathrm{A}+\mathrm{B}+\mathrm{C}+\mathrm{D}+\mathrm{E}+\mathrm{F}+\mathrm{G}+\mathrm{H}+\mathrm{I}) \times 100}{156}
$$

Keterangan:

R : Nilai rancangan RPP

1 : Nilai Komponen RPP

A : Jumlah nilai identitas RPP

B : Jumlah nilai KI

C : Jumlah nilai KD dan IPK

D : Jumlah nilai tujuan pembelajaran

E : Jumlah nilai materi pembelajarn

F : Jumlah nilai metode pembelajaran

G : Jumlah nilai media/alat/sumber belajar

$\mathrm{H}$ : Jumlah nilai Kegiatan Pembelajaran

I : Jumlah penilaian

Tingkat kemampuan dalam menyusun RPP akan dikonversikan dalam bentuk penilaian dengan menggunakan rubrik penilaian pada table sebagai berikut:

Tabel 1. Pedoman Penilaian RPP

\begin{tabular}{|c|l|l|}
\hline Skor & \multicolumn{1}{|c|}{ Kriteria } & \multicolumn{1}{|c|}{ Keterangan } \\
\hline 1 & $\begin{array}{l}\text { tidak sesuai, tidak lengkap, tidak jelas, tidak operasional, } \\
\text { tidak sistematis }\end{array}$ & Tidak baik \\
\hline 2 & $\begin{array}{l}\text { sesuai, kurang jelas, kurang lengkap, kurang operasional, } \\
\text { kurang sistematis }\end{array}$ & Cukup baik \\
\hline 3 & $\begin{array}{l}\text { sebagian besar sesuai, jelas, lengkap, operasional, } \\
\text { sistematis }\end{array}$ & Baik \\
\hline 4 & semua sesuai, jelas, lengkap, operasional, sistematis & Sangat baik \\
\hline
\end{tabular}

Data hasil penilaian RPP mahasiswa akan analisis dengan menggunakan statistik deskripstif dengan ketentuan pada tabel berikut;

Tabel 2. Ketegori Penilaian RPP

\begin{tabular}{|l|l|}
\hline \multicolumn{1}{|c|}{ Rentang } & \multicolumn{1}{c|}{ Kategori } \\
\hline$>50$ & Sangat tidak baik \\
\hline $50-59$ & Tidak baik \\
\hline $60-69$ & Cukup baik \\
\hline $70-79$ & Baik \\
\hline $80-100$ & Sangat baik \\
\hline
\end{tabular}

Setelah data terkumpul, langkah selanjutnya adalah menganalisis data. Analisis data yang digunakan dalam penelitian ini adalah teknik analisis statistik deskriptif dengan menghitung rata-rata skor hasil rancangan RPP Tematik mahasiswa Pendidikan Guru Madrasah Ibtidaiyah kemudian dideskripsikan dalam bentuk narasi. 


\section{HASIL PENELITIAN DAN PEMBAHASAN}

Hasil riset terhadap kemampuan Mahasiswa Pendidikan Guru Madrasah Ibtidaiyah Sekolah Tinggi Agama Islam Darul Ulum Kandangan dalam merancangRPP tematik dideskripsikan dengan menggunakan Indikator Penilaian Kinerja Guru (IPKG-1) untuk setiap RPP yang dibuat oleh mahasiswa. Dokumen RPP yang dinilai sebanyak 31 dokumen RPP dan disajikan hasilnya berdasarkan data penilaian RPP secara perorangan. Agar lebih jelas berikut data terkait penilaian RPP yang disajikan dalam tabel berikut:

Tabel 3. Analisis Penilaian Terhadap RPP Rancangan Mahasiswa Secara Perorangan

\begin{tabular}{|c|c|c|c|c|}
\hline No. & Nama & Total Nilai & Nilai Akhir & Kategori \\
\hline 1 & R1 & 106 & 67.9 & $\bar{C}$ \\
\hline 2 & R2 & 129 & 82.7 & A \\
\hline 3 & R3 & 95 & 60.9 & $\bar{C}$ \\
\hline 4 & $\overline{\mathrm{R}} 4$ & 116 & 74.4 & $\bar{B}$ \\
\hline 5 & R5 & 99 & 63.5 & $\mathrm{C}$ \\
\hline 6 & R6 & 102 & 65.4 & C \\
\hline 7 & R7 & 109 & 69.9 & $\mathrm{C}$ \\
\hline 8 & $\mathrm{R} 8$ & 124 & 79.5 & B \\
\hline 9 & R9 & 102 & 65.4 & $\mathrm{C}$ \\
\hline 10 & $\mathrm{R} 10$ & 109 & 69.9 & $\mathrm{C}$ \\
\hline 11 & $\mathrm{R} 11$ & 118 & 75.6 & $\mathrm{~B}$ \\
\hline 12 & $\mathrm{R} 12$ & 100 & 64.1 & $\mathrm{C}$ \\
\hline 13 & $\mathrm{R} 13$ & 79 & 50.6 & $\mathrm{D}$ \\
\hline 14 & R14 & 87 & 55.8 & $\overline{\mathrm{D}}$ \\
\hline 15 & R15 & 108 & 69.2 & $\mathrm{C}$ \\
\hline 16 & R16 & 96 & 61.5 & $\mathrm{C}$ \\
\hline 17 & R17 & 95 & 60.9 & $\mathrm{C}$ \\
\hline 18 & R18 & 100 & 64.1 & $\bar{C}$ \\
\hline 19 & R19 & 91 & 58.3 & D \\
\hline 20 & R20 & 57 & 36.5 & $\bar{E}$ \\
\hline 21 & R21 & 91 & 58.3 & $\bar{D}$ \\
\hline 22 & R22 & 89 & 57.1 & $\mathrm{D}$ \\
\hline 23 & R23 & 79 & 50.6 & $\mathrm{D}$ \\
\hline 24 & R24 & 88 & 56.4 & $\mathrm{D}$ \\
\hline 25 & R25 & 60 & 38.5 & $\mathrm{E}$ \\
\hline 26 & R26 & 88 & 56.4 & $\overline{\mathrm{D}}$ \\
\hline 27 & R27 & 71 & 45.5 & $\bar{E}$ \\
\hline 28 & R28 & 77 & 49.4 & $\mathrm{E}$ \\
\hline 29 & R29 & 66 & 42.3 & $\bar{E}$ \\
\hline 30 & R30 & 72 & 46.2 & $\bar{E}$ \\
\hline 31 & R31 & 101 & 64.7 & $\mathrm{C}$ \\
\hline \multicolumn{4}{|c|}{ Rata-Rata Kelas } & 60.0 \\
\hline
\end{tabular}

Berdasarkan hasil analisis terkait kemampuan mahasiswa secara perorangan dalam merancang RPP tematik dapat dikategorikan "Cukup Baik" dengan nilai rata-rata kelas sebesar 61,9. Hal ini dapat dilihat pada tabel 3. Berdasarkan tabel tersebut, hanya 1 orang mahasiswa yang mendapatkan kategori nilai "Sangat Baik" dengan bobot nilai 82,7. Adapun mahasiswa yang mendapatkan kategori nilai "Baik", yakni dengn rentang nilai 70-79 sebanyak 4 orang. Untuk kategori nilai "Cukup Baik" dengan rentang nilai 60-69 sebanyak 12 orang. Kategori nilai "Kurang Baik" dengan rentang nilai 50-59 ada 9 orang dan ketegori nilai 
"Sangat Tidak Baik" dengan rentang nilai kurang dari 50 ada 5 orang. Agar lebih mudah dipahami lihat pada tabel 4 berikut:

Tabel 4 Penilaian RPP Berdasarkan Kategori Nilai

\begin{tabular}{|c|c|c|c|}
\hline No & Kategori & Frekuensi & $\%$ \\
\hline 1 & A & 1 & 0,31 \\
\hline 2 & B & 3 & 0,93 \\
\hline 3 & $\mathrm{C}$ & 13 & 4,03 \\
\hline 4 & $\mathrm{D}$ & 8 & 2,48 \\
\hline 5 & $\mathrm{E}$ & 6 & 1,86 \\
\hline \multicolumn{2}{|c|}{ Jumlah } & 31 & 100 \\
\hline
\end{tabular}

Data tersebut kemudian dirinci berdasarkan masing-masing komponen. Ada 10 komponen RPP yang ditelaah dalam penelitian ini berdasarkan rubrik penlaian RPP yang diadaptasi dari Instrumen Penilaian Kinerja Guuru (IPKG-1), dan dimodifikasi berdasarkan keperluan penelitian. Komponen-komponen tersebut diantaranya ialah 1) nilai komponen RPP secara umum, 2) identitas RPP, 3) kompetensi inti, 4) kompetensi dasar dann indikator pencapaian kompetensi (IPK), 5) tujuan pembelajaran, 6) materi pembelajaran, 7) metode pembelajaran, 8) media/alat/sumber belajar, 9) kegiatan pembelajaran, dan 10) penilaian.

Hasil riset menunjuukan ada beberapa nilai komponen yang dikategorikan "Cukup Baik", diantaranya adalah perumusan indikator dan tujuan pembelajaran, materi, metode, media, sumber belajar, kegiatan pembelajaran, dan penilaian yang mendapatkan skor nilai rata-rata 2,0-2,9. Ada juga yang telah mencapai kategori "Baik", yakni pada Identitas RPP, KI, dan penilaian komponen RPP secara umum berada pada rentang nilai 3,0-3,9. Berikut akan dipaparkan secara lebih rinci hasil analisis terhadap RPP tematik per komponen pada tabel 5:

Tabel 5. Analisis Penilaian RPP Mahasiswa Perkomponen

\begin{tabular}{|c|l|c|c|}
\hline No. & \multicolumn{1}{|c|}{ Komponen yang Dinilai } & Jumlah Nilai & $\begin{array}{c}\text { Rata-rata Skor } \\
\text { Komponen }\end{array}$ \\
\hline 1 & Nilai komponen RPP secara umum & 387 & 3.1 \\
\hline 2 & Identitas RPP & 324 & 3.5 \\
\hline 3 & Kompetensi Inti & 120 & 3.9 \\
\hline 4 & Kompetensi Dasar dan IPK & 262 & 2.8 \\
\hline 5 & Tujuan Pembelajaran & 63 & 2.0 \\
\hline 6 & Materi Pembelajaran & 61 & 2.0 \\
\hline 7 & Metode Pembelajaran & 284 & 2.3 \\
\hline 8 & Media/Alat/Sumber belajar & 226 & 2.4 \\
\hline 9 & Kegiatan Pembelajaran & 800 & 2.9 \\
\hline 10 & Penilaian & 251 & 2.0 \\
\hline
\end{tabular}

Berdasarkan hasil analisis, pada komponen indikator atau IPK, didapatkan rata-rata skor nilai sebesar 2,8, yakni berada pada kategori nilai "Cukup Baik." Dalam hal ini menunjukkan bahwa rata-rata mahasiswa memiliki kemampuan dalam merumuskan indikator berdasarkan KD yang ada, meskipun dalam prosesnya memiliki beberapa kendala.

Pada Komponen tujuan pembelajaran berdasarkan hasil dokumentasi dan analisis ditemukan bahwa rata-rata tujuan yang dirancang tidak menggambarkan adanya tujuan pembelajaran yang memuat aspek Audience, Behaviour, Condition, dan Degree, bahkan sebagian ada yang tidak mencantumkan tujuan pembelajaran secara rinci dan dapat diukur. Hal inilah yang mengakibatkan skor nilai pada tujuan pembelajaran hanya pada kategori "Cukup Baik", yakni dengan rata-rata skor nilai 2,0. 
Komponen materi pembelajaran juga mendapatkan rata-rata skor nilai 2,0 berada pada ketegori "cukup baik". Data hasil telaah RPP berdasarkan IPKG menujukkan bahwa rata-rata mahasiswa hanya mencantumkan garis besar materi pembelajaran dalam buku pelajaran yang sesuai dengan kurikulum yang berlaku, yang mereka rasa sesuai dengan tujuan pembelajaran, akan tetapi tidak menyusun materi secara rinci dan sistematis berdasarkan masing-masing tujuan, serta tidak mencantumkannya dalam RPP.

Komponen berikutnya adalah metode pembelajaran yang juga berada pada rata-rata skor nilai 2,3 berada pada kategori nilai "Cukup Baik". Hal ini sesuai dengan hasil analisis, ditemukan bahwa metode yang digunakan oleh mahasiswa belum mengarah pada pendekatan saintifik, kebanyakan masih berkutat pada metode penugasan, latihan dan ceramah, kemudian metode yang dirancang sering tidak nampak pada kegiatan inti dalam RPP, bahkan ada beberapa yang tidak mencantumkan jenis metode yang akan digunakan dalam pembelajaran.

Komponen berikutnya adalah penilaian, diantara komponen yang lain hanya komponen penilaian ini dan tujuan pembelajaran yang mendapatkan rata-rata nilai paling rendah, yakni dengan rata-rata skor nilai 2,0. Berdasarkan hasil analisis ditemukan bahwa, racangan penilaian yang dicantumkan dalam RPP tidak lengkap. Rata-rata mahasiswa tidak menuliskan jenis penialaian yang akan digunakan, dan tidak membuat rubrik penilaian. Bahkan jika rubrik dibuat hanya mencontoh rubrik penilaian yang ada pada buku guru, tidak menyesuaiakan dengan indikator pembelajaran yang dirumuskan.

Setelah ditelaah berdasarkan format penyusunan RPP secara umum, rancangan RPP mahasiswa sudah memenuhi standar dalam hal komponen RPP yang diatur dalam Peraturan Menteri Pendidikan dan Kebudayaan Nomor 22 Tahun 2016 tentang Standar Proses Pendidikan Dasar dan Menengah, dalam peraturan tersebut dijelaskan bahwa komponen RPP setidaknya memuat identitas RPP (identitas sekolah, identitas mata pelajaran, kelas, semester, materi pokok, dan alokasi waktu), Kompetensi Inti, Kompetensi Dasar, tujuan pembelajaran, materi pembelajaran (memuat fakta, konsep, pronsip dan prosedur yang relevan, dan ditulis dalam bentuk butir-butir sesuai dengan rumusan indikator), metode pembelajaran, media, sumber, kegiatan yang berisi langkah-langkah pembelajaran (kegiatan pembuka, inti dan penutup), dan penialian hasil belajar siswa (Kemdikbud, 2016). Maka dari itu RPP dibuat dengan sistematis dan runtut.

Data penelitian ini juga diambil berdasarkan wawancara untuk menggali informasi terkait kendala yang dihadapi selama merancang RPP tematik. Berdasarkan hasil wawancara dengan mahasiswa, mereka mengalami beberapa kendala dalam merancang RPP tematik ini, kendala yang mereka hadapi di antaranya adalah merumuskan indikator dalam hal ini yang dimaksud adalah indikator pencapaian kompetensi (IPK) berdasarkan kompetensi dasar (KD) dan merancang tujuan pembelajaran. Kemudian berdasarkan hasil telaah komponen RPP berupa tujuan pembelajaran, beberapa RPP ditemui tidak mencantumkan komponen tersebut, sebagian ada yang mecantumkan namun kurang lengkap, dan sebagian kecil lengkap atau sangat lengkap dengan tujuan pembelajaran memuat aspek Audience, Behaviour, Condition, dan Degree.

Adapun kendala lainnya adalah menentukan metode pembelajaran yang cocok bagi siswa sesuai dengan tingkat berfikir dan materi, hal ini berkaitan erat dengan penentuan kegiatan pembelajaran yang memuat kegiatan 5M. Selain itu, komponen media dan sumber belajar juga masih berada pada ketegori "Cukup Baik" dengan rata-rata skor nilai sebesar 2,4. Mahasiswa juga merasa kesulitan ketika merancang penilaian.

Berikut akan diuraikan lebih lanjut kendala yang dihadapi oleh mahasiswa. Adapun kendala-kendala yang diuraikan dalam analisis data ini merupakan kendala yang paling banyak dihadapi oleh mahasiswa selama merncang RPP tematik tersebut, yakni; 


\section{Perumusan Indikator Pencapaian Kompetensi (IPK)}

Indikator Pencapaian Kompetensi (IPK) didefinisikan sebagai pengukur sikap peserta didik melalui obsevasi untuk menunjukkan ketercapaian suatu KD (Azizan M. A., 2019). Berdasarkan data yang telah disajikan sebelumnya, diketahui bahwa perumusan Indikator Pencapaian Kompetensi (IPK) memiliki kendala berarti bagi mahasiswa. Mahasiswa terkendala dalam merumuskan Indikator Pencapaian Kompetensi (IPK) ini kerena harus menyesuaikan dengan KD. Dimana dalam prosesnya Indikator Pencapaian Kompetensi (IPK) ini harus sesuai dengan taraf berfikir siswa, merumuskan berdasarkan kata kerja operasional yang relevan, dan akhirnya IPK ini akan mempengaruhi langkah selanjutnya mulai dari penentuan tujuan pembelajaran sampai pada penilaian hasil belajar. Indikator Pencapaian Kompetensi (IPK) juga harus dirumuskan berdasarkan pada KD dengan menggunakan kata kerja operasional (KKO). Kata kerja operasional yang menjadi rujukan pada umumnya diambil dari teori Taksonomi Bloom.

Hal ini senada dengan Prinsip Penyusunan RPP berdasarkan Peraturan Menteri Pendidikan dan Kebudayaan Nomor 22 Tahun 2016 tentang Standar Proses Pendidikan Dasar dan Menengah, disebutkan bahwa dalam menyusun RPP hendaknya memperhatikan penekanan pada keterkaitan dan keterpaduan antara KD, materi, kegiatan, indikator pencapaian kompetensi, penilaian, dan sumber belajar ke dalam satu kesatuan pengalaman belajar (Kemdikbud, 2016). Lebih lanjut juga disebutkan bahwa dalam menyusun RPP termasuk di dalamnya merumuskan Indikator Pencapaian Kompetensi perlu memperhatikan kemampuan awal, tingkat intelektual, bakat, minat, emosi, motivasi, gaya belajar serta kecepatan belajar siswa. (Azizan M. A., 2019). Pada dasarnya setiap KD dikembangkan minimal menjadi satu Indikator Pencapaian Kompetensi yang operasional dan minimal dengan level kompetensi yang setara sebagai basis untuk penyusuna instrumen penilaian (Prastowo, 2019). Maka dari itu kendala yang dihadapi ini relevan dengan nilai hasil analisis RPP pada komponen Indikator, yang mana pada tahap ini mahasiswa masih dikategorikan "Cukup Baik".

\section{Merumuskan Tujuan Pembelajaran}

Perumusan tujuan pembelajaran yang baik ialah dirumuskan berdasarkan KD dengan memperhatikan empat unsur dalam perumusan tujuan yaitu Audience, Behavior, Condition, dan Degree (Prastowo, 2019). Empat unsur yang disebutkan oleh Pastowo tersebut, sebagian besar tidak ditemukan dalam RPP tematik yang dirancang oleh mahasiswa. Sebagaimana data hasil wawancara yang telah dipaparkan sebelumnya, mahasiswa merasa terkendala dalam merumuskan tujuan ini.

Selain terkait perumusan tujuan pembelajaran yang memuat empat unsur tersebut, mahasiswa juga terkendala dalam merumuskan tujuan ini dengan menggunakan kata kerja yang operasional. Sebagian juga tidak mencantumkan tujuan pembelajaran sesuai dengan banyaknya butir-butir Indikator Pencapaian Kompetensi. Berdasarkan Peraturan Menteri Pendidikan dan Kebudayaan Nomor 22 Tahun 2016 tentang Standar Proses Pendidikan Dasar dan Menengah, dalam merumuskan tujuan pembelajaran harus berdasarkan KD dengan menggunakan kata kerja operasional yang dapat diamati dan diukur, yang mencakup pengetahuan, sikap dan keterampilan (Kemdikbud, 2016)

\section{Pemilihan Metode}

Pemilihan metode pembelajaran merupakan suatu yang harus dilakukan guru dalam merancang RPP. Metode pembelajaran yang digunakan oleh guru hendaknya mampu mewujudkan suasana belajar dan proses pembelajaran yang mampu membantu siswa mencapai KD dan Indikator Pencapaian Kompetensi (IPK) yang telah ditetapkan. Maka dengan demikian, pemilihan metode pembelajaran juga sangat perlu diperhatikan. 
Komponen metode pembelajaran dalam RPP ini memuat tentang pemilihan pendekatan, model, dan strategi pembelajaran yang dipilih. Pemilihan metode dalam merancang RPP tematik ini memiliki kendala, mahasiswa terkendala dalam memilih metode yang sesuai dengan materi dan pembelajaran yang berorientasi pada pendekatan saintifik yang memuat proses pembelajaran 5M (mengamati, menanya, mencoba, menalar, dan mengomunikasikan), dan menyesuaikan dengan model atau strategi pembelajaran yang relevan. Bahkan ada sebagian RPP yang hanya mencamtumkan metode saja tanpa ada pendekatan dan model pembelajaran.

Ada beberapa model pembelajaran yang disarankan untuk pembelajaran tematik terpadu berdasarkan Permendikbud RI No. 57 Tahun 2014 tentang kurikulum Sekolah Dasar dan Madrasah Ibtidaiyah yaitu model pembelajaran langsung, model pembelajaran kooperatif, model pembelajaran kontekstual, model pembelajaran penemuan terbimbing dan problem based learning (Kemdikbud, 2014)

\section{Pemilihan Media, Alat, dan Sumber Belajar}

Berdasarkan hasil analisis data ditemukan bahwa, media yang dirancang cukup bervariasi, sesuai tujuan pembelajaran dan taraf berfikir siswa, serta mampu membuat siswa terlibat dalam penggunaan media tersebut, akan tetapi untuk sumber belajar rata-rata hanya menggunakan sumber dari buku paket, tidak memanfaatkan sumber belajar lain yang mungkin banyak tersedia disekitar siswa.

Pemilihan media dan sumber belajar hendaknya dapat memudahkan siswa dalam proses pembelajaran dan dapat membantu siswa untuk mencapai tujuan pembelajaran. Hal ini telah disebutkan dalam prinsip penyusunan RPP berdasarkan Peraturan Menteri Pendidikan dan Kebudayaan Nomor 22 Tahun 2016 tentang Standar Proses Pendidikan Dasar dan Menengah, disebutkan bahwa media pembelajaran merupakan alat bantu dalam proses pebelajaran untuk menyampaikan materi. Sedangkan sumber belajar dapat berupa buku, media cetak lainnya ataupun media elektronik, alam sekitar, atau sumber belajar lain yang juga relevan (Kemdikbud, 2016). Maka dari itu, rancangan terhadap media dan sumber belajar kurang bervariasi, sehingga masih dikategorikn "Cukup Baik."

\section{Kegiatan Pembelajaran}

Secara umum, hasil temuan kegiatan pembelajaran pada RPP tematik ini bagus, semuanya memuat kegiatan pendahuluan, inti, dan penutup. Idealnya langkah-langkah pelaksanaan pembelajaran tematik terpadu meliputi tiga komponen utama, yaitu kegiatan pendahuluan, inti, dan penutup (Prastowo, 2019). Akan tetapi pada proses perancangannya mahasiswa terkendala dalam menyusun setiap kegiatan pembelajaran tersebut.

Data hasil analisis menunjukkan bahwa pada kegiatan pendahuluan, yang mana memuat kegiatan penyampaian tujuan, apersepsi dan motivasi. Pada kegiatan apersepsi dan motivasi banyak mahasiswa yang melewatkan langkah tersebut, dan sebagian hanya menyebutkan langkah tanpa menjelaskan. Sehingga rancangan pada kegiatan pendahuluan menjadi kurang maksimal.

Adapun pada kegiatan inti, mahasiswa kurang spesifik dalam merancang kegiatan yang menampilkan adanya proses pembelajaran saintifik. Hal ini tentu saja karena pengaruh pemilihan metode pada tahap sebelumnya dan kebingungan mahasiswa dalam memadukan beberapa mata pelajaran menjadi satu kesatuan. Kegiatan pembelajaran pada pembelajaran tematik berdasarkan Peraturan Menteri Pendidikan dan Kebudayaan Nomor 22 Tahun 2016 tentang Standar Proses Pendidikan Dasar dan Menengah yaitu menggunakan model pembelajaran, metode pembelajaran, media pembelajaran, dan sumber belajar yang sesuai dengan karakteristik peserta didik dan mata pelajaran (Kemdikbud, 2016). 
Pada kegiatan penutup sebagaimana yang disebutkan dalam Peraturan Menteri Pendidikan dan Kebudayaan Nomor 22 Tahun 2016 tentang Standar Proses Pendidikan Dasar dan Menengah, dinyatakan bahwa dalam kegiatan penutup, guru dan peserta didik baik secara individu maupun kelompok hendaknya melakukan kegiatan refleksi untuk mengevaluasi seluruh kegiatan pembelajaran, memberikan umpan balik terhadap proses dan hasil pembelajaran, dan memberikan tindak lanjut dalam bentuk pemberian tugas, baik berupa tugasi individu maupun tugas kelompok, serta menginformasikan rencana pertemuan berikutnya (Kemdikbud, 2016).

Pada faktanya, rancangan pada kegiatan tersebut belum maksimal. Yang mana banyak ditemukan rancangan yang hanya memuat kegiatan menyimpulkan, dan tindak lanjut berupa pemberian tugas, tanpa adanya kegiatan refleksi terhadap seluruh rangkaian aktivitas pembelajaran yang telah dilakukan dan pemberian umpan balik terhadap proses atau hasil pembelajaran.

\section{Penilaian Hasil Belajar}

Penilaian merupakan salah satu komponen yang sangat penting dalam merancang RPP, dimana ketika tujuan telah ditentukan maka turut menentukan penilaian. Penilaian merupakan sebuah proses pengumpulan data dan informasi untuk menentukan ketercapaian hasil belajar siswa.penilaian tersebut dilakukan oleh guru dengan cara melihat kemampuan peserta didik dari segala aspek (pengetahuan, sikap, dan keterampilan) (Azizan M. A., 2019). Oleh karena itu, mengingat bahwa RPP yang dirancang oleh mahasiswa merupakan RPP tematik, maka penilaian pada pembelajaran tematik harus dinilai secara holistik dengan proses penilaian autentik.

Berdasarkan paparan data sebelumnya terkait penilaian dalam RPP tematik yang dirancang mahasiswa, dapat disimpulkan bahwa kemampuan mahasiswa dalam merancang penilaian masih berada pada kategori "Cukup Baik". Mengingat ada beberapa kendala yang dihadapi oleh mahasiswa, penilaian dianggap komponen yang sulit setelah perumusan Indikator Pencapaian Kompetensi. Hasil analisis juga menunjukkan bahwa penilaian yang dibuat mahasiswa tidak lengkap, sebagian hanya menyebutkan jenis penilaian tanpa mencantumkan rubrik dan contoh soal, sebagian yang lain mencantumkan namun kurang sesuai dengan tujuan pembelajaran, dan sebagian yang lain tidak mencantumkan sama sekali baik jenis maupun contoh soal dan rubrik penilaian

\section{PENUTUP}

Berdasarkan hasil pembahasan, maka dapat disimpulkan sebagai berikut.

1. Kemampuan mahasiswa Pendidikan Guru Madrasah Ibtidaiyah STAI Darul Ulum Kandangan dalam merancangRPP Tematik pada mata kuliah Strategi dan Perencanaan Pembelajaran dikategorikan "Cukup Baik" dengan rata-rata kelas sebesar 60,9. Indikator Penilaian Kinerja Guru (IPKG-1) menunjukkan bahwa komponenRPP Tematik identitas RPP, KI, Komponen RPP secara umum mendapatkan skor nilai 3,0-3,9 berada padakategori nilai "Baik". Sedangkan pada komponen perumusan indikator pencapaian kompetensi (IPK), perumusan tujuan pembelajaran, memilih metode, media dan sumber belajar, materi pembelajaran ,kegiatan pembelajarn dan penilaian mendapatkan skor nilai 2,0-2,9, yakni berada pada ketegori "Cukup Baik".

2. Kendala yang dihadapi mahasiswa selama merancangRPP Tematik diantaranya ialah perumusan indikator pencapaian kompetensi (IPK), perumusan tujuan pembelajaran, memilih metode, media dan sumber belajar, kegiatan pembelajaran dan penilaian. Yang paling menonjol diantara semuanya adalah kendala dalam perumusan indikator pencapaian kompetensi (IPK), perumusan tujuan pembelajaran dan penilai 


\section{DAFTAR PUSTAKA}

Azizan, M. A. (2019). Pembelajaran Tematik SD-MI. Yogyakarta: Samudra Biru.

Daryanto. (2014). Pembelajaran Tematik, Terpadu ,Terintegrasi (Kurikulum 2013). Yogyakarta: Gava Media.

Depag RI. (2009). Pedoman Penyusunan Pembelajaran Tematik Pendidikan Agama Islam (PAI) Sekolah Dasar (SD) Tahun 2009. Jakarta: Depag RI.

Depdiknas. (2003). Undang-Undang Republik Indonesia Nomor 20 Tahun 2003 tentang Sistem Pendidikan Nasional. Jakarta: Depdiknas.

Hartono, R. (2013). Ragam Model Pembelajaran yang Mudah Diterima Murid. Yogyakarta: Diva Press.

Kemdikbud. (2014). Peraturan Menteri Pendidikan dan Kebudayaan RI Nomor 19 Tahun 2014 tentang Pembelajaran pada Pendidikan Dasar dan Menengah. Jakarta: Kemdikbud.

.......... (2014). Peraturan Menteri Pendidikan dan Kebudayaan RI Nomor 103 Tahun 2014 tentang Pembelajara pada Pendidikan Dasar dan Menengah. Jakarta: Kemdikbud.

... (2014). Peraturan Menteri Pendidikan dan Kebudayaan RI Nomor 57 Tahun 2014 tentang Kurikulum Sekolah Dasar dan Madrasah Ibtidaiyah. Jakarta: Kemdikbud.

(2016). peraturan Menteri Pendidikan dan Kebudayaan RI Nomor 22 tahun 2016 tentang Standar Proses Pendidikan Dasar dan Menengah. Jakarta: Kemdikbud.

Prastowo, A. (2019). Analisis Pembelajaran Tematik Terpadu. Jakarta: PrenadaMedia.

Sugiyono. (2015). Metode Penelitian Pendidikan Pendekatan Kualitatif, dan R\&D. Bandung: Alfabeta.

Suhendra, A. (2019). Implementasi Kurikulum 2013 Dalam Pembelajaran SD\MI. Jakarta: PrenadaMedia.

Sundayana, W. (2017). Telaah Kurikulum dan Perencanaan Pembelajaran . Jakarta: Erlangga.

Suseno, T. I.-T. (2017). Desain Pengembangan Kurikulum 2013 di Madrasah. Depok: Kencana.

Suseno, T. I.-T. (2017). Desain Pengembangan Kurikulum 2013 di Madrasah. Depok: Kencana.

Suwandi, B. (2008). Memahami Penelitian Kualitatif. Jakarta: Rineka Cipta.

Widyastono, H. (2015). Pengembangan Kurikulum di Era Otonomi Daerah dari Kurikulum 2004,2006, ke Kurikulum 2013. Jakarta: Bumi Aksara. 